\title{
Metabolism of the Insecticide Isofenphos in Rats
}

\author{
Masako Ueji and Chojiro Tomizawa \\ National Institute of Agro-Environmental Sciences, \\ Yatabe-machi, Tsukuba-gun, Ibaraki 305, Japan
}

(Received October 13, 1986)

\begin{abstract}
Distribution, metabolism and excretion of $[0$-ethyl-1-14 $\mathrm{C}]$ isofenphos were examined in rats. When rats were orally administered with ${ }^{14} \mathrm{C}$-isofenphos, the ${ }^{14} \mathrm{C}$-compounds were distributed over the whole body $6 \mathrm{hr}$ after administration and decreased gradually with time. ${ }^{14} \mathrm{C}-$ Compounds in the liver were persistent. Greater part of radiocarbon excreted from rats was recovered from the urine, and smaller part from the feces and the expired air. When metabolites in the urine and feces were partitioned between benzene and water, most of radiocarbon was recovered from the water fraction, and only small part from the benzene fraction and unextractable residues. Aminoisofenphos and isofenphos-oxon were identified as benzene soluble metabolites, and six metabolites were identified as water soluble metabolites, which include $O$-ethyl hydrogen phosphoramidate, $O$-ethyl hydrogen isopropylphosphoramidothioate and others. The results suggested that cleavage of $\mathrm{P}-\mathrm{O}-$ aryl linkage took place dominantly in isofenphos metabolism in rats compared with that of $\mathrm{P}-\mathrm{N}$ linkage.
\end{abstract}

\section{INTRODUCTION}

Isofenphos $(O$-ethyl $O$-2-isopropoxycarbonylphenyl isopropylphosphoramidothioate) is very effective and persistent in controlling soil insects such as Popillia japonica Newman and Anomala cuprea Hope. ${ }^{1-4)}$ It was found that high insecticidal activity of isofenphos was not dependent on the inhibition of AChE activity by isofenphos-oxon, but on the oxidative activation of isofenphos or isofenphos-oxon in the rat liver microsome-NADPH system or the chemical treatment with peracid.5) Moreover, it was reported that isofenphos was metabolized in vitro dominantly into $O$-ethyl hydrogen isopropylphosphoramidate through isofenphosoxon in the rat liver microsome-NADPH system. $\left.{ }^{6}\right)$

In vivo metabolism of isofenphos in rats was examined using $\left[\right.$ ring- ${ }^{14} \mathrm{C}$ ]isofenphos. The results proved that a main metabolic pathway of isofenphos was the formation of isopropyl salicylate in conjugated and unconjugated forms through isofenphos-oxon. ${ }^{7}$ This paper deals with in vivo metabolism of isofenphos in rats using $[O$-ethyl-1-14 $\mathrm{C}]$ isofenphos.

\section{MATERIALS AND METHODS}

\section{Chemicals}

$\left[O\right.$-Ethyl- $\left.1-{ }^{14} \mathrm{C}\right]$ isofenphos was synthesized according to the procedure described previously, $\left.{ }^{6}\right)$ with the radiochemical purity, $99.7 \%$ and the specific activity, $3.12 \mathrm{mCi} / \mathrm{mmol} .[N-$ Isopropyl-2- ${ }^{14} \mathrm{C}$ ] isofenphos with its radiochemical purity, $99.2 \%$ and the specific activity, $1.25 \mathrm{mCi} / \mathrm{mmol}$, was synthesized in the same way as described in the previous report. ${ }^{6)}$ The latter compound was used only for the wholebody autoradiography in the experiment. Isofenphos (I), $O$-ethyl $O$-2-isopropoxycarbonylphenyl phosphoramidothioate (II, aminoisofenphos), $O$-ethyl $O$-2-isopropoxycarbonylphenyl isopropylphosphoramidate (III, isofenphos-oxon), $O$-ethyl $O$-2-isopropoxycarbonylphenyl hydrogen phosphorothioate (IV, $\operatorname{des} N$-isopropyl isofenphos), $O$-ethyl hydrogen isopropylphosphoramidothioate (V), desphenyl isofenphos), $O$-ethyl $O$-2-isopropoxycarbonylphenyl hydrogen phosphate (VI, des $N$-isopropyl isofenphos-oxon) and $O$-ethyl hydrogen iso- 
Table $1 \quad R f$ values of isofenphos and its metabolites in TLC.

\begin{tabular}{|c|c|c|c|c|c|c|}
\hline & \multirow{2}{*}{ Compounds } & & \multicolumn{4}{|c|}{$R f$ values in solvent system ${ }^{a}$} \\
\hline & & & $\mathrm{A}$ & B & $\mathrm{C}$ & $\mathrm{D}$ \\
\hline $\mathbf{I}$ & Isofenphos & $\begin{array}{l}\mathrm{C}_{2} \mathrm{H}_{5} \mathrm{O} \\
\mathrm{R}_{1} \mathrm{NH}\end{array} \mathrm{P}(\mathrm{S}) \mathrm{OR}_{2}{ }^{\mathrm{b})}$ & 0.54 & 0.82 & & \\
\hline II & Aminoisofenphos & $\underset{\mathrm{NH}_{2}}{\mathrm{C}_{2} \mathrm{H}_{5} \mathrm{O}}>\mathrm{P}(\mathrm{S}) \mathrm{OR}_{2}$ & 0.35 & 0.30 & & \\
\hline III & Isofenphos-oxon & $\begin{array}{l}\mathrm{C}_{2} \mathrm{H}_{5} \mathrm{O} \\
\mathrm{R}_{1} \mathrm{NH}\end{array}>\mathrm{P}(\mathrm{O}) \mathrm{OR}_{2}$ & 0.25 & 0.20 & & \\
\hline IV & $\begin{array}{l}\text { Des } N \text {-isopropyl } \\
\text { isofenphos }\end{array}$ & $\underset{\mathrm{HO}}{\mathrm{C}_{2} \mathrm{H}_{5} \mathrm{O}}>\mathrm{P}(\mathrm{S}) \mathrm{OR}_{2}$ & & & 0.93 & 0.90 \\
\hline $\mathbf{V}$ & $\begin{array}{l}\text { Desphenyl } \\
\text { isofenphos }\end{array}$ & $\begin{array}{l}\mathrm{C}_{2} \mathrm{H}_{5} \mathrm{O} \\
\mathrm{R}_{1} \mathrm{NH}\end{array}>\mathrm{P}(\mathrm{S}) \mathrm{OH}$ & & & 0.87 & 0.80 \\
\hline VI & $\begin{array}{l}\text { Des } N \text {-isopropyl } \\
\text { isofenphos-oxon }\end{array}$ & 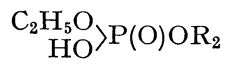 & & & 0.61 & 0.50 \\
\hline VII & $\begin{array}{l}\text { Desphenyl } \\
\text { isofenphos-oxon }\end{array}$ & $\begin{array}{l}\mathrm{C}_{2} \mathrm{H}_{5} \mathrm{O} \\
\mathrm{R}_{1} \mathrm{NH}\end{array}>\mathrm{P}(\mathrm{O}) \mathrm{OH}$ & & & 0.54 & 0.25 \\
\hline VIII & $\begin{array}{l}O \text {-Ethyl hydrogen } \\
\text { phosphoramidate }\end{array}$ & $\underset{\mathrm{NH}_{2}}{\mathrm{C}_{2} \mathrm{H}_{5} \mathrm{O}}>\mathrm{P}(\mathrm{O}) \mathrm{OH}$ & & & 0.44 & 0.13 \\
\hline \multirow[t]{6}{*}{ IX } & $\begin{array}{l}O \text {-Ethyl dihydrogen } \\
\text { phosphate }\end{array}$ & $\underset{\mathrm{HO}}{\mathrm{C}_{2} \mathrm{H}_{5} \mathrm{O}}>\mathrm{P}(\mathrm{O}) \mathrm{OH}$ & & & 0.06 & 0.08 \\
\hline & Unknown I & & 0.44 & 0.71 & & \\
\hline & Unknown II & & 0.15 & 0.12 & & \\
\hline & Unknown III & & & & 0.73 & 0.66 \\
\hline & Unknown IV & & & & 0.23 & 0.14 \\
\hline & Unknown V & & & & 0.15 & 0.10 \\
\hline
\end{tabular}

a) A, hexane: acetone (5:2); B, benzene: $\mathrm{MeOH}(20: 1)$; C, 2-propanol: $\mathrm{NH}_{4} \mathrm{OH}: \mathrm{H}_{2} \mathrm{O}(75: 10: 15)$; $\mathrm{D}, n-\mathrm{BuOH}: \mathrm{AcOH}: \mathrm{H}_{2} \mathrm{O}(80: 5: 5)$.

b)

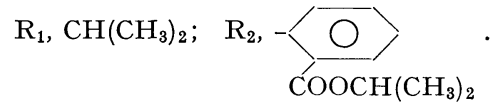

propylphosphoramidate (VII, desphenyl isofenphos-oxon) were also prepared as described in the previous papers. ${ }^{5,6}$

$O$-Ethyl hydrogen phosphoramidate (VIII) was prepared by desmethylation of $O$-ethyl $O$ methyl phosphoramidate with potassium xanthogenate. Mass spectrum of the methylated product was $m / z 139[\mathrm{M}]^{+}, 125\left[\mathrm{M}-\mathrm{CH}_{2}\right]^{+}, 123$ $\left[\mathrm{M}-\mathrm{NH}_{2}\right]^{+}$and $109\left[\mathrm{M}-\mathrm{CH}_{2} \mathrm{O}\right]^{+}$.

$O$-Ethyl dihydrogen phosphate $(\mathbf{I X})$ : Barium salt of $O$-ethyl phosphate was supplied by Dr. T. Shishido, National Institute of AgroEnvironmental Sciences, and converted into a free form with sulfuric acid. Mass spectrum of the methylated product was $m / z \quad 154[\mathrm{M}]^{+}, 140$ $\left[\mathrm{M}-\mathrm{CH}_{2}\right]^{+}, 126\left[\mathrm{M}-\mathrm{C}_{2} \mathrm{H}_{4}\right]^{+}, 111\left[\left(\mathrm{CH}_{3} \mathrm{O}\right) \mathrm{OP}(\mathrm{O})\right.$ $\mathrm{OH}]^{+}$and $95\left[\left(\mathrm{CH}_{3} \mathrm{O}\right) \mathrm{P}(\mathrm{O}) \mathrm{OH}\right]^{+}$.

\section{Thin-layer Chromatography (TLC)}

Precoated silica gel $20 \times 20 \mathrm{~cm} \quad 60 \mathrm{GF}_{254}$ chromatoplates (E. Merck, Germany, thickness: $0.2 \mathrm{~mm}$ ) were used for preparative and analytical purposes. The solvent system and the $R f$ values for the authentic compounds are summarized in Table 1. ${ }^{14} \mathrm{C}$-Metabolites derived from $\left[O\right.$-ethyl- $\left.1-{ }^{14} \mathrm{C}\right]$ isofenphos were identified by co-chromatography with the authentic compounds. The sulfur, nitrogen or phosphorus containing compounds were detected by spraying chromogenic reagents as reported previously ${ }^{6)}$ or exposing under 254 nm UV light.

\section{Animal Treatment}

Three Wistar rats (7 weeks old, 180-200 g body weight) were orally administered with $1.23 \mathrm{mg}$ of $\left[O\right.$-ethyl- $\left.1-{ }^{14} \mathrm{C}\right]$ isofenphos in $1.0 \mathrm{ml}$ of $10 \%$ Tween 80 solution, and housed in a glass metabolic cage (Crown Glass Co. Ltd., U.S.A.) at $24-26^{\circ} \mathrm{C}$. For the metabolic study on 
${ }^{14} \mathrm{C}$-isofenphos, the urine and feces were collected separately, and the expired air was trapped in a mixture of monoethanolamine and methylcellosolve $(1: 1)$ at appropriate intervals. The experiments were conducted triplicately.

\section{Whole-Body Autoradiography}

Wistar male rats (4 weeks old, $130-140 \mathrm{~g}$ ) orally administered with $7.0 \mathrm{mg} / \mathrm{kg}(8.2 \mu \mathrm{Ci})$ of $\left[O\right.$-ethyl- $\left.1-{ }^{14} \mathrm{C}\right]$ isofenphos or $7.4 \mathrm{mg} / \mathrm{kg} \quad(3.5$ $\mu \mathrm{Ci})$ of $\left[N\right.$-isopropyl-2 $\left.-{ }^{14} \mathrm{C}\right]$ isofenphos, were anesthetized with ethyl ether $6,24,48 \mathrm{hr}$ and 7 days after administration of the former, and $6,24,48 \mathrm{hr}$ and 14 days after administration of the latter, and frozen at $-20^{\circ} \mathrm{C}$ until the preparation of whole-body autoradiography. Sections with $40 \mu \mathrm{m}$ thickness were prepared by an autocryotome (Type NA-200, Nakagawa Seisakusho, Japan) and after lyophilizing, the sections were kept on macro autoradiograph film $\left({ }^{3} \mathrm{H}\right.$ type, Sakura MARG ${ }^{\circledR}$, Konishiroku Photo Ind. Co. Ltd., Japan) at $5^{\circ} \mathrm{C}$ for 4 weeks.

5. Analysis of ${ }^{14} \mathrm{C}$-Isofenphos and Its $\mathrm{Me}$ tabolites

For determination of radioactivity in the urine, feces and expired air, aliquots of the urine and mixtures of monoethanolamine and methylcellosolve $(1: 1)$ containing the expired air were put into vials for radioassay on a liquid scintillation spectrometer (Aloka LSC 673). Aliquots of the feces were combusted with a sample oxidizer (Packard 306) before radioassay. For examination of metabolites, two-fold volume $(\mathrm{v} / \mathrm{v})$ of benzene was added to the urine, and ${ }^{14} \mathrm{C}$-compounds were partitioned between benzene and water. The feces were homogenized with ten-fold volume $(v / w)$ of
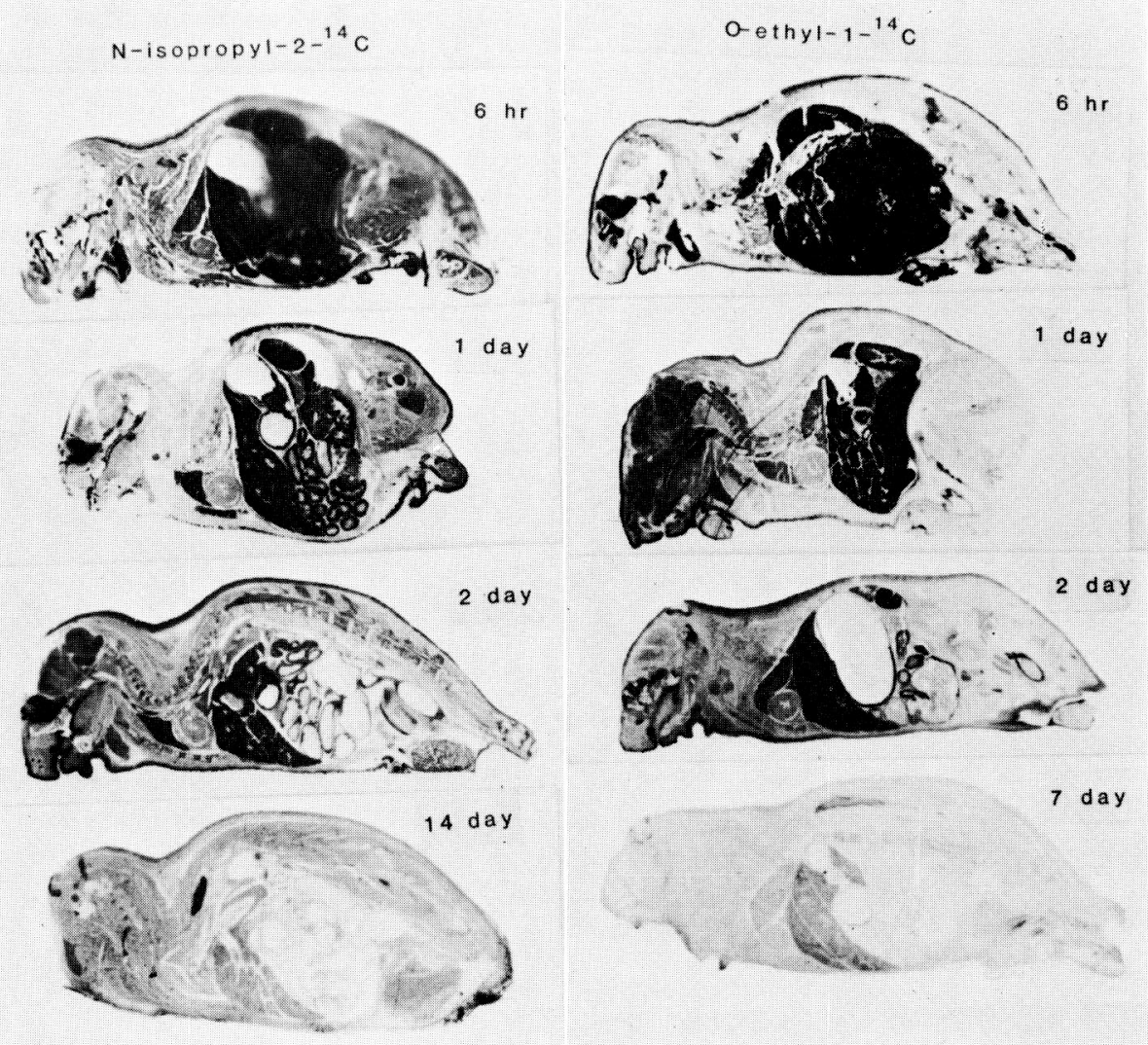

Fig. 1 Autoradiograms showing the distribution of radioactivity in the rat administered with ${ }^{14} \mathrm{C}$-isofenphos.

Left, $[N$-isopropyl-2-14 $\mathrm{C}]$ isofenphos; right, $[O$-ethyl-1-14 $\mathrm{C}]$ isofenphos. 
benzene and water $(1: 1)$, and filtered. Aliquots of the benzene and aqueous fractions were taken for radioassay. Unextractable residues after filtration of fecal homogenates were combusted with a sample oxidizer, and their radioactivity was determined. The remainders of the benzene fraction were concentrated in vacuo to examine metabolites of $\left[O\right.$-ethyl- $\left.1-{ }^{14} \mathrm{C}\right]-$ isofenphos. The benzene fraction was passed through the Florisil column with ethyl acetate to remove the materials which would interfer with TLC. The aqueous fraction was lyophilized, and the residues suspended again in $0.1 \mathrm{ml}$ of methanol were applied to TLC. Radioactive metabolites on the plates were detected by autoradiography, and their radioactivity was determined after scraping appropriate silica gel regions.

\section{RESULTS AND DISCUSSION}

\section{Distribution of Radiocarbon Derived from ${ }^{14} \mathrm{C}$-Isofenphos in Rat Body}

As shown in Fig. $1,{ }^{14} \mathrm{C}$ was distributed over the whole body, especially in the stomach, liver, kidney, lung, intestine and eyeball $6 \mathrm{hr}$ after administration with ${ }^{14} \mathrm{C}$ isofenphos, and radioactivity in the organs declined gradually with time. The decrease of ${ }^{14} \mathrm{C}$ in the liver and eyeball was very slowly, and a low level of ${ }^{14} \mathrm{C}$ remained in the liver even 14 days after administration with $\left[N\right.$-isopropyl-2- $\left.{ }^{14} \mathrm{C}\right]$ isofenphos. In the whole-body autoradiograms of rats administered with other ${ }^{14} \mathrm{C}$-organophosphorus compounds, $\left[\right.$ ring $\left.{ }^{14} \mathrm{C}\right]$ fenitrothion $(O$, $O$-dimethyl $O$-3-methyl-4-nitrophenyl phosphorothioate) and $\left[\right.$ ring $\left.{ }^{14} \mathrm{C}\right]$ tolclofos-methyl $(O$ 2, 6-dichloro-4-methylphenyl $O, O$-dimethyl phosphate), radiocarbon was distributed over the whole organs such as the stomach, intestine, liver and kidney just after administration, while ${ }^{14} \mathrm{C}$ was almost completely excreted within $24 \mathrm{hr}^{8,9)}$ However, radiocarbon remained for a considerably long period in rats administered with $\left[O\right.$-ethyl-1- $\left.{ }^{14} \mathrm{C}\right]$ - or $\left[N\right.$-isopropyl-2- $\left.{ }^{14} \mathrm{C}\right]$ isofenphos compared with those $\left[\right.$ ring $\left.{ }^{14} \mathrm{C}\right]$ labeled organophosphorus compounds. Different from the radiocarbon derived from $\left[\right.$ ring $\left.-{ }^{14} \mathrm{C}\right]$ labeled compounds, the radiocarbon derived from $[O$ ethyl-1- $\left.{ }^{14} \mathrm{C}\right]$ - and $\left[N\right.$-isopropyl-2- $\left.{ }^{14} \mathrm{C}\right]$ isofenphos was probably incorporated into the processes of anabolism and catabolism of normal metab-

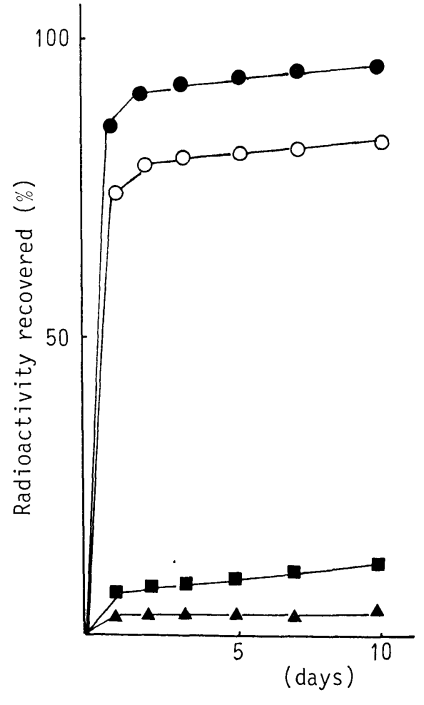

Fig. 2 Excretion of radiocarbon from rats orally administered with $[O$-ethyl-1-14 $\mathrm{C}]$ isofenphos.

- total ${ }^{14} \mathrm{C}$; $\mathrm{O},{ }^{14} \mathrm{C}$ in urine; ${ }^{14} \mathrm{C}$ in expired air.

olites, and therefore, excretion of the radiocarbon was very slow.

\section{Excretion}

Figure 2 shows the recovery of radioactivity in the urine, feces and expired air excreted from rats administered with $\left[O\right.$-ethyl- $\left.1-{ }^{14} \mathrm{C}\right]$ isofenphos. Recovery of radiocarbon in the urine, feces and expired air was $83.3 \%$ one day after administration. Radiocarbon was excreted mainly in the urine throughout the experimental period, and approximately $78.9 \%$ of the dosed radiocarbon was found in the urine. Moreover, radiocarbon was excreted by $10.2 \%$ in feces and by $2.7 \%$ in the expired air. It was possible that ${ }^{14} \mathrm{CO}_{2}$ and (or) volatile metabolites in the expired air were produced via deethylation of $\left[O\right.$-ethyl- $\left.1-{ }^{14} \mathrm{C}\right]$ isofenphos. ${ }^{10)}$

\section{Fractionation of ${ }^{14} \mathrm{C}$-Isofenphos and Its $\mathrm{Me}$ - tabolites}

Distribution of radiocarbon between the benzene and aqueous fractions of ${ }^{14} \mathrm{C}-\mathrm{com}$ pounds in the urine and feces was shown in Table 2. Greater part of radiocarbon in the urine was recovered from the aqueous fraction, suggesting that isofenphos was rapidly trans- 
Table 2 Distribution of radiocarbon recovered from the urine and feces of rats orally administered with $[O$-ethyl-1-14 $\mathrm{C}]$ isofenphos.

\begin{tabular}{|c|c|c|c|c|c|}
\hline \multirow{2}{*}{$\begin{array}{c}\text { Days after } \\
\text { administration }\end{array}$} & \multicolumn{2}{|c|}{$\begin{array}{l}\text { Recovery of radiocarbon } \\
\text { in the urine }\end{array}$} & \multicolumn{3}{|c|}{$\begin{array}{l}\text { Recovery of radiocarbon } \\
\text { in the feces }\end{array}$} \\
\hline & $\begin{array}{c}\text { Benzene } \\
\text { fraction ( } \%)\end{array}$ & $\begin{array}{c}\text { Aqueous } \\
\text { fraction }(\%)\end{array}$ & $\begin{array}{c}\text { Benzene } \\
\text { fraction (\%) }\end{array}$ & $\begin{array}{c}\text { Aqueous } \\
\text { fraction }(\%)\end{array}$ & $\begin{array}{l}\text { Unextractable } \\
\text { residues }(\%)\end{array}$ \\
\hline 1 & $0.08 \pm 0.02$ & $73.03 \pm 3.52$ & $1.79 \pm 0.38$ & $4.51 \pm 0.83$ & $1.58 \pm 0.29$ \\
\hline 2 & $0.03 \pm 0.01$ & $3.78 \pm 0.45$ & $0.21 \pm 0.08$ & $0.81 \pm 0.15$ & $0.46 \pm 0.14$ \\
\hline 3 & $0.01 \pm 0.00$ & $0.78 \pm 0.23$ & $0.05 \pm 0.02$ & $0.07 \pm 0.03$ & $0.13 \pm 0.02$ \\
\hline 4,5 & $<0.01$ & $0.59 \pm 0.16$ & $0.05 \pm 0.01$ & $0.05 \pm 0.02$ & $0.11 \pm 0.03$ \\
\hline 6,7 & $<0.01$ & $0.39 \pm 0.09$ & $0.03 \pm 0.01$ & $0.04 \pm 0.02$ & $0.10 \pm 0.03$ \\
\hline $8,9,10$ & $<0.01$ & $0.21 \pm 0.04$ & $0.03 \pm 0.01$ & $0.04 \pm 0.01$ & $0.13 \pm 0.02$ \\
\hline
\end{tabular}

Values represent the mean \pm S.E. of 3 rats $\times 3$ replicates.

formed into the water soluble metabolites. Radiocarbon in the feces was also distributed mainly in the aqueous fraction. However, the ratio of the benzene soluble metabolites one day after administration was higher in the feces than in the urine, and it seemed that part of the parent compounds was excreted directly into the feces without being degraded in the digestive tracts. Radiocarbon in the benzene, aqueous fractions and unextractable residues decreased gradually with time.

\section{Examination of ${ }^{14} \mathrm{C}$-Metabolites}

Isofenphos metabolites in the benzene fraction were separated by TLC using solvent systems A (hexane: acetone, 5: 2) and B (benzene: methanol, 20:1). Five metabolites including two unidentified spots and metabolite(s) located at the origin of TLC were found. Isofenphos, aminoisofenphos and isofenphos-oxon were identified by co-chromatography with the authentic compounds, and unknown I and II were detected as shown in Table 1. Metabolites in the aqueous fraction were separated by TLC using solvent systems $\mathrm{C}$ (2-propanol: $\mathrm{NH}_{4} \mathrm{OH}$ : $\left.\mathrm{H}_{2} \mathrm{O}, 75: 10: 15\right)$ and $\mathrm{D}$ (n-butanol: $\mathrm{AcOH}$ : $\mathrm{H}_{2} \mathrm{O}, 80: 5: 5$ ), and $\operatorname{des} N$-isopropyl isofenphos, desphenyl isofenphos, $\operatorname{des} N$-isopropyl isofenphos-oxon, desphenyl isofenphos-oxon, $O$-ethyl hydrogen phosphoramidate and $O$-ethyl dihydrogen phosphate were identified by cochromatography with the authentic compounds. Moreover, unknown III, IV and V were detected. Their $R f$ values of these compounds are shown in Table 1.
Table 3 shows the distribution of metabolites in the urine and feces of rats orally administered with $\left[O\right.$-ethyl- $\left.1-{ }^{14} \mathrm{C}\right]$ isofenphos. The figures in the table represents percentages to the initial radioactivity one day to three days after administration with ${ }^{14} \mathrm{C}$-isofenphos, and the variety of metabolites derived from ${ }^{14} \mathrm{C}$ isofenphos was the same throughout the period of metabolism study. Recovery of radiocarbon after 4 days of administration was negligible. It was found that a very small amount of benzene soluble compounds including isofenphos was excreted into the urine and feces until 3 days after administration. As for the water soluble metabolites in the excreta, the main metabolite was $O$-ethyl hydrogen phosphoramidate and the ratios of $\mathrm{P}=\mathrm{S}$ and $\mathrm{P}=\mathrm{O}$ containing metabolites in the excreta varied with day.

$\left[O\right.$-Ethyl- $\left.1-{ }^{14} \mathrm{C}\right]$ isofenphos was transformed rapidly into water soluble metabolites in rats, and the metabolites were excreted mainly through the urine and feces. In the metabolism study on other phosphoramidates in rats, crufomate, $O-\left[1-{ }^{14} \mathrm{C}\right] 4$-tert-butyl-2-chlorophenyl $O$-methyl methylphosphoramidate, was not found in both the urine and feces $48 \mathrm{hr}$ after administration, ${ }^{11)}$ and butamifos, $O$-ethyl $O-3$ methyl-6-[ring- $\left.{ }^{3} \mathrm{H}\right]$ nitrophenyl sec-butylphosphoramidothioate was found only in the feces $48 \mathrm{hr}$ after administration and its recovery was less than $1 \%$ of the dosed radioactivity. ${ }^{12)}$ Moreover, more than $90 \%$ of butamifos metabolites was formed through cleavage of $\mathrm{P}-\mathrm{O}-$ aryl linkage, ${ }^{12)}$ suggesting that deamination in rats 
Table 3 Percentage of radiocarbon recovered from the urine and feces of rats orally administered with $[O$-ethyl-1-14 $\mathrm{C}]$ isofenphos.

\begin{tabular}{|c|c|c|c|c|c|c|}
\hline \multirow{3}{*}{ Compound } & \multicolumn{6}{|c|}{ Days after administration } \\
\hline & \multicolumn{3}{|c|}{ Urine } & \multicolumn{3}{|c|}{ Feces } \\
\hline & 1 & 2 & 3 & 1 & 2 & 3 \\
\hline \multicolumn{7}{|l|}{ Benzene fraction } \\
\hline$\underset{\mathrm{R}_{1} \mathrm{NH}}{\stackrel{\mathrm{EtO}}{ }}>\mathrm{P}(\mathrm{S}) \mathrm{OR}_{2}$ & $0.05 \pm 0.02$ & 0.01 & 0.01 & $1.28 \pm 0.15$ & $0.09 \pm 0.02$ & 0.02 \\
\hline$\underset{\mathrm{NH}_{2}}{\mathrm{EtO}}>\mathrm{P}(\mathrm{S}) \mathrm{OR}_{2}$ & $<0.01$ & $<0.01$ & $<0.01$ & $0.06 \pm 0.01$ & 0.02 & 0.01 \\
\hline $\begin{array}{r}\mathrm{EtO} \\
\mathrm{R}_{1} \mathrm{NH}\end{array}>\mathrm{P}(\mathrm{O}) \mathrm{OR}_{2}$ & 0.01 & 0.01 & $<0.01$ & $0.35 \pm 0.08$ & 0.04 & 0.02 \\
\hline Unknown I & $<0.01$ & $<0.01$ & $<0.01$ & $<0.01$ & 0.01 & 0.01 \\
\hline Unknown II & 0.02 & $<0.01$ & $<0.01$ & $0.04 \pm 0.01$ & 0.01 & $<0.01$ \\
\hline $\begin{array}{c}\text { Metabolites at } \\
\text { the origin }\end{array}$ & $<0.01$ & $<0.01$ & $<0.01$ & $0.05 \pm 0.02$ & 0.01 & $<0.01$ \\
\hline \multicolumn{7}{|l|}{ Aqueous fraction } \\
\hline$\underset{\mathrm{HO}}{\mathrm{EtO}}>\mathrm{P}(\mathrm{S}) \mathrm{OR}_{2}$ & $1.37 \pm 0.21$ & 0.06 & 0.02 & $0.15 \pm 0.05$ & $0.06 \pm 0.02$ & $<0.01$ \\
\hline$\underset{\mathrm{R}_{1} \mathrm{NH}}{\mathrm{EtO}}>\mathrm{P}(\mathrm{S}) \mathrm{OH}$ & $15.68 \pm 1.35$ & $0.93 \pm 0.28$ & $0.10 \pm 0.02$ & $0.35 \pm 0.14$ & $0.07 \pm 0.03$ & 0.01 \\
\hline$\underset{\mathrm{HO}}{\mathrm{E} \mathrm{O}}>\mathrm{P}(\mathrm{O}) \mathrm{OR}_{2}$ & $11.89 \pm 2.30$ & $0.36 \pm 0.09$ & $0.13 \pm 0.03$ & $0.95 \pm 0.32$ & $0.19 \pm 0.05$ & $<0.01$ \\
\hline $\begin{array}{r}\mathrm{EtO} \\
\mathrm{R}_{1} \mathrm{NH}\end{array}>\mathrm{P}(\mathrm{O}) \mathrm{OH}$ & $6.64 \pm 0.95$ & $0.31 \pm 0.15$ & 0.06 & $0.32 \pm 0.10$ & $0.04 \pm 0.02$ & 0.01 \\
\hline$\underset{\mathrm{NH}_{2}}{\mathrm{EtO}}>\mathrm{P}(\mathrm{O}) \mathrm{OH}$ & $24.95 \pm 5.32$ & $1.37 \pm 0.43$ & $0.31 \pm 0.14$ & $1.59 \pm 0.43$ & $0.22 \pm 0.08$ & $<0.01$ \\
\hline$\underset{\mathrm{HO}}{\mathrm{EtO}}>\mathrm{P}(\mathrm{O}) \mathrm{OH}$ & $2.10 \pm 0.18$ & $0.19 \pm 0.2$ & 0.04 & $0.13 \pm 0.07$ & 0.01 & $<0.01$ \\
\hline Unknown III & $6.19 \pm 0.83$ & $0.38 \pm 0.11$ & $0.08 \pm 0.02$ & $0.35 \pm 0.17$ & $0.10 \pm 0.02$ & $<0.01$ \\
\hline Unknown IV & $2.29 \pm 0.56$ & $0.08 \pm 0.02$ & 0.02 & $0.16 \pm 0.06$ & 0.03 & $<0.01$ \\
\hline Unknown $\mathrm{V}$ & $1.58 \pm 0.69$ & 0.07 & 0.02 & $0.30 \pm 0.09$ & 0.05 & 0.02 \\
\hline $\begin{array}{l}\text { Metabolites at } \\
\text { the origin }\end{array}$ & $0.32 \pm 0.07$ & 0.02 & $<0.01$ & $0.21 \pm 0.06$ & 0.03 & $<0.01$ \\
\hline
\end{tabular}

Values represent the mean \pm S.E. of 3 rats $\times 3$ replicates.

$\mathrm{Et}, \mathrm{CH}_{2} \mathrm{CH}_{3} ; \mathrm{R}_{1}, \mathrm{CH}\left(\mathrm{CH}_{3}\right)_{2} ; \mathrm{R}_{2},-\frac{\mathrm{O}}{\mathrm{COOCH}\left(\mathrm{CH}_{3}\right)_{2}}$.

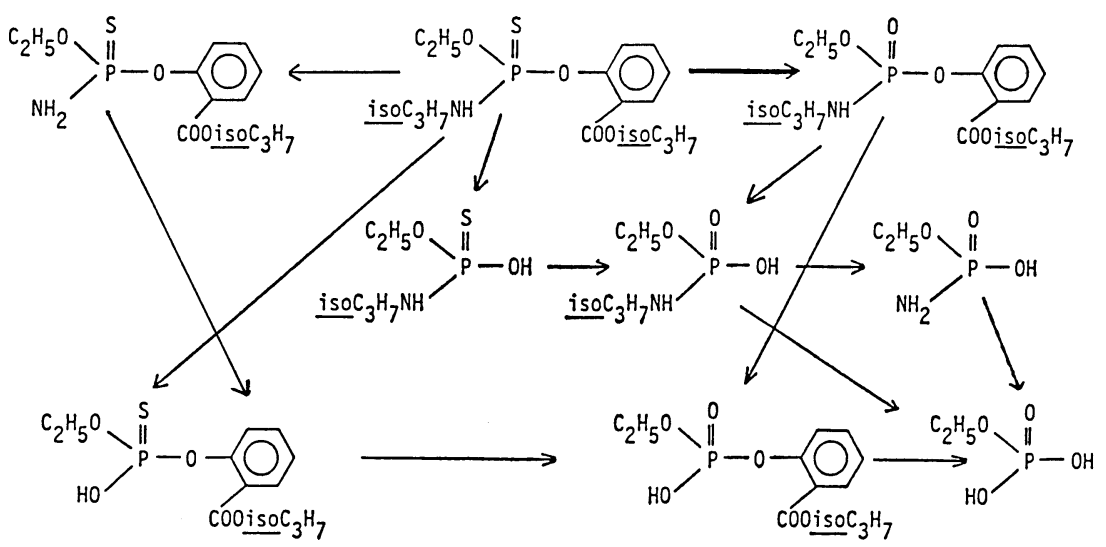

Fig. 3 Proposed metabolic pathways of isofenphos in rats. 
was regarded as a minor pathway of butamifos. Water soluble metabolites of isofenphos were formed through cleavage of $\mathrm{P}-\mathrm{O}-$ aryl or $\mathrm{P}-\mathrm{N}$ linkage, and desaryl compounds was formed in larger amounts than $\operatorname{des} N$-isopropyl compounds. In rats administered with $\left[\right.$ ring $\left.-{ }^{14} \mathrm{C}\right]$ isofenphos, isopropyl salicylate in both the conjugated and unconjugated forms was found as main metabolites in the urine, and $O$-ethyl $O$ hydroxyhippuric acid and salicylic acid in conjugated and unconjugated forms and $\mathrm{N}$ desisopropyl isofenphos-oxon were found as minor metabolites. ${ }^{7)}$ The result of the experiments with ${ }^{14} \mathrm{C}$-isofenphos labeled at different positions indicated that isofenphos was transformed easily into desaryl compounds in rats. In the metabolism of $\left[O\right.$-ethyl- $\left.1-{ }^{14} \mathrm{C}\right]$ isofenphos, the main metabolite was $O$-ethyl hydrogen isopropylphosphoramidate in vitro ${ }^{6}$ and $O$ ethyl hydrogen phosphoramidate in vivo. This result suggested that the $\mathrm{N}-\mathrm{C}$ linkage was split easily in vivo. From the above mentioned results, metabolic pathways of isofenphos in rats are proposed as shown in Fig. 3.

\section{ACKNOWLEDGMENTS}

The authors express their thanks to Dr. T. Shishido, National Institute of Agro-Environmental Sciences, for his valuable suggestions and Dr. N. Motoyama, Chiba University, for supplying metabolic cages.

\section{REFERENCES}

1) K. O. Lawrences: J. Econ. Entomol. 74, 543 (1981)

2) H. Tashiro, T. D. Spittler \& E. Greco: J. Econ. Entomol. 75, 906 (1982)

3) M. Hagiwara \& F. Kobayashi: J. Jpn. For. Soc. 90, 387 (1979)
4) M. Hagiwara \& F. Kobayashi: J. Jpn. For. Soc. 92, 353 (1981)

5) M. Ueji \& C. Tomizawa: J. Pesticide Sci. 9, 675 (1984)

6) M. Ueji \& C. Tomizawa: J. Pesticide Sci. 10, 691 (1985)

7) Pesticide Residues in Food: "1981 Evaluations, The Monograph," FAO, JMPR, Rome, p. 258, 1982

8) J. Miyamoto, K. Mihara \& S. Hosokawa: J. Pesticide Sci. 1, 9 (1976)

9) K. Mihara, H. Ohkawa \& J. Miyamoto: J. Pesticide Sci. 6, 65 (1981)

10) H. T. Appleton \& T. Nakatsugawa: Pestic. Biochem. Physiol. 7, 451 (1977)

11) J. E. Bakke \& C. E. Price: J. Environ. Sci. Health B12, 251 (1977)

12) K. Mihara, K. Nambu, Y. Misaki \& J. Miyamoto: J. Pesticide Sci. 1, 207 (1976)

\section{要 約}

\section{殺虫剤イソフェンホスのラットにおける代謝}

上路雅子，富澤長次郎

イソフェンホスの $O$-エチル基を ${ }^{14} \mathrm{C}$ で標識した化合 物を用いて，ラットにおける吸収，代謝および排泄につ いて調べた．経口投与した ${ }^{14} \mathrm{C}-$ 化合物は処理 6 時間まで に全身に分布し，その後減衰したが肝臓では長期間残留 した。 ${ }^{14} \mathrm{C}-$ 化合物はおもに尿中に排泄されたほか，粪， 呼気中からも回収された。投与された ${ }^{14} \mathrm{C}$-イソフェン ホスの代謝は速やかであり，代謝物の大部分は水溶性代 謝物であった，同定された代謝物は，有機溶媒可溶性代 謝物として微量の aminoisofenphos, isofenphos-oxon と, 水溶性代謝物として主代謝物の $O$-ethyl hydrogen phosphoramidate, $O$-ethyl hydrogen isopropylphosphoramidothioate を含む 6 化合物であった.なお, イソフェンホ スの主代謝経路は P-O-aryl 結合の開裂に伴う水溶性代 謝物の生成であった。 